\title{
A new species and new combinations in Melicope (Rutaceae) in New South Wales
}

\author{
T.G. Hartley
}

\begin{abstract}
Hartley, T.G. (Australian National Herbarium, Division of Plant Industry, CSIRO, G.P.O. Box 1600, Canberra, A.C.T. 2601) 1990. A new species and new combinations in Melicope (Rutaceae) in New South Wales. Telopea 4(1): 33-35. Melicope hayesii T. Hartley is described as new and new combinations in Melicope are made for three species previously included in Euodia.
\end{abstract}

Melicope J.R. \& G. Forster and Euodia J.R. \& G. Forster are being revised. The notes that follow are provided so that the names are available for use in the forthcoming Flora of New South Wales. The new classification of Melicope and Euodia has been discussed by Hartley (1981) and Hartley and Stone (1989).

\section{Melicope hayesii T. Hartley, sp. nov.}

Arbor 5-18 m alta; ramulis et foliis glabris; foliis trifoliolatis, $6.5-16 \mathrm{~cm}$ longis; petiolo. 2-6 cm longo; lamina foliolorum lateralium ovato-elliptica, anguste ovato-elliptica, elliptica, vel anguste elliptica lamina terminali elliptica vel anguste elliptica, 3.7-9 $\times$ 1.2-4 cm; inflorescentiis axillaribus, multifloris, $2.5-6 \times 2.5-5 \mathrm{~cm}$, axe et ramis glabris vel fere glabris, pedicellis glabris vel sparse et minute puberulis, $2-4.5 \mathrm{~mm}$ longis; floribus bisexualibus; petalis albis, abaxialiter glabris, adaxialiter in $1 / 2$ proximali villosis, 3-3.5 mm longis, caducis; staminibus 4; gynoecio glabro; carpellis fructificantibus in $1 / 5$ proximali connatis, divergentibus, c. $5 \mathrm{~mm}$ longis, endocarpio puberulo vel sparse pubescenti, persistenti.

TYPE: QueEnSLAND: Moreton District: Springbrook, Carricks Road near Purling Brook, L.W. Jessup 466 (CANB, holotype; BRI, isotype, not seen).

Tree 5-18 m high; indumentum of simple trichomes. Young branchlets $2.5-3.5 \mathrm{~mm}$ wide, with the leaves glabrous; terminal bud glabrous or nearly so (sometimes unevenly clothed with stiff, appressed trichomes - apparently an abnormal condition). Leaves trifoliolate, $6.5-16 \mathrm{~cm}$ long; petiole $2-6 \mathrm{~cm}$ long, $0.8-1 \mathrm{~mm}$ wide; petiolule in lateral leaflets obsolete or up to $5 \mathrm{~mm}$ long, in terminal leaflet 1-9 $\mathrm{mm}$ long; leaflet blades subcoriaceous, in lateral leaflets ovate-elliptic to elliptic or narrowly so, in terminal leaflet elliptic or narrowly so, 3.7-9 $\times 1.2-4 \mathrm{~cm}$, the base acute to attenuate, the midrib prominent to plane (sometimes with narrow median ridge) above, the main veins prominulous above, in terminal leaflet 12-16 per side, diverging from midrib at $60-70^{\circ}$ angle, the apex acuminate. Inflorescences axillary, many-flowered, 2.5-6 $\times$ $2.5-5 \mathrm{~cm}$, the peduncle $0.7-2 \mathrm{~cm}$ long, with the distal axis and branches glabrous or nearly so, the pedicels glabrous to sparsely and minutely puberulent, 2-4.5 $\mathrm{mm}$ long (3-5 mm long in fruit). Flowers bisexual; calyx glabrous or nearly so, $0.7-1 \mathrm{~mm}$ long, the sepals connate only at base, suborbicular, persistent in fruit; petals white, imbricate, villous in proximal $1 / 2$ adaxially, otherwise glabrous, 3-3.5 $\mathrm{mm}$ long, becoming recurved distally, caducous after anthesis; stamens 4, 4-5 mm long, the filament with a few trichomes near base adaxially or glabrous, subulate to filiform at apex, the anther 1.5-2.3 mm long; disc with a few tufts of trichomes at top or glabrous; gynoecium glabrous, 3-4.5 $\mathrm{mm}$ long, the style including stigma $2-3.5 \mathrm{~mm}$ long, the stigma scarcely differentiated from style, $0.2-0.3 \mathrm{~mm}$ wide. Fruiting carpels connate in proxi$\mathrm{mal} \mathrm{1/5}$, divergent, ellipsoid, about $5 \mathrm{~mm}$ long, the epicarp coriaceous, glabrous, the 
endocarp cartilaginous, puberulent or sparsely pubescent, persistent. Seeds ovoid, about $3.5 \mathrm{~mm}$ long; funiculus broad, flattened.

DiSTRIBUTION. South-east Queensland and north-east New South Wales; recorded from rainforest and margins; 140-900 $\mathrm{m}$.

AdDITIONAL SPECIMENS EXAMINED: QuEENSLAND: Darling Downs District: The Head, near Killarney, W.T. Jones, Oct 1967 (CANB). Moreton District: Springbrook, Clemens 42874 (A), W.T. Jones C 21 SN 5552 (CANB), Schodde 5597 (CANB); Portion 83 Tallebudgera, Upper Currumbin Creek, W.J.F. McDonald 3288 (CANB). New South Wales: North Coast: Lamington National Park, Floyd, 25.5.1961 (Coffs Harbour); Nullum State Forest, Hayes (BRI); Whian Whian State Forest, Constable, 15.1.1953 (NSW), Johnson \& Constable, 10.6.1957 (NSW), W.T. Jones 1234 (CANB), 2989 SN 7714 (CANB), Moriarty 707 (BRI, CANB), Tracey C81 SN5610 (CANB), Webb. \& Tracey, 1953-58 (BRI, CANB), Webb \& White 2112 (BRI); Moonpah State Forest, Hayes, Jan 1956 (Coffs Harbour), 25.6.1958 (NSW); Coramba, Boorman, Nov 1912 (NSW); East Dorrigo, W.T. Jones 4 (BRI), June 1946 (Coffs Harbour); between Thora and Dorrigo, Salasoo 1891 (NSW); Dorrigo State Forest, White 7557A (BRI); Bellingen District, Hewitt, Apr 1946 (NSW); Bellinger River, W. MacDonald 23 (MEL); Pine Creek State Forest near Repton, Wells, 19.9.1958 (NSW); Bellangry State Forest, Hayes \& Floyd, 6.11.1958 (Coffs Harbour).

Melicope hayesii appears to be most closely related to M. micrococca (F.Muell.) T. Hartley, differing mainly in its ovate-elliptic to elliptic (as opposed to usually obovate) leaflet blades, its glabrous (as opposed to hirtellous) gynoecium, and its caducous (as opposed to usually persistent in fruit) petals.

The geographic range of Melicope hayesii is entirely within that of M. micrococca, and both species have been collected from similar habitats in Lamington National Park, Whian Whian State Forest, and Bellangry State Forest. Their flowering periods are about the same.

The epithet hayesii commemorates Harold C. Hayes, formerly rainforest botanist with the Forestry Commission of New South Wales.

Melicope elleryana (F. Muell.) T. Hartley, comb. nov.

Euodia elleryana F. Muell., Fragm. 5: 4 (1865).

Type: Queensland: Port Curtis District, Beddome Creek, Thozet (MEL, holotype).

Melicope micrococca (F. Muell.) T. Hartley, comb. nov.

Euodia micrococca F. Muell., Fragm. 1: 144 (1859).

Type: New South Wales: Central Coast, Cabramatta, Woolls (MEL, holotype).

Euodia micrococca var. pubescens Fraser \& Vickery, Proc. Linn. Soc. New South Wales 62: 289 (1937).

Type: New South Wales: North Coast, Bellingen, Fraser \& Vickery, 26.1.1936 (NSW, holotype).

Melicope vitiflora (F. Muell.) T. Hartley, comb. nov.

Euodia vitiflora F. Muell., Fragm. 7: 144 (1871).

Type: Queensland: North Kennedy District, Rockingham Bay, Dallachy (MEL, holotype). 


\section{Acknowledgments}

Thanks are extended to the directors and curators of A, BRI, CANB, MEL, NSW, and Forestry Commission of New South Wales at Coffs Harbour for making specimens in their care available to me.

\section{References}

Hartley, T.G. (1981) A revision of the genus Tetradium (Rutaceae). Gard. Bull. Singapore 34: $91-131$.

Hartley, T.G., \& Stone, B.C. (1989) Reduction of Pelea with new combinations in Melicope (Rutaceae). Taxon 38: 119-123.

Manuscript received 24 October 1989

Manuscript accepted 15 March 1990 